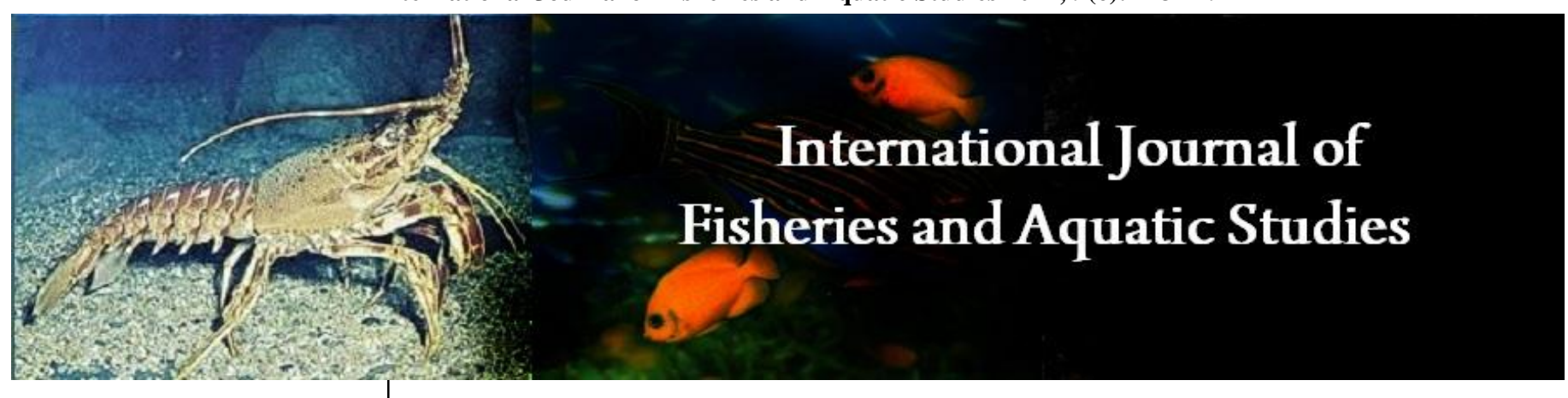

E-ISSN: 2347-5129

P-ISSN: 2394-0506

(ICV-Poland) Impact Value: 5.62

(GIF) Impact Factor: 0.549

IJFAS 2021; 9(6): 113-119

(C) 2021 IJFAS

www.fisheriesjournal.com

Received: 13-09-2021

Accepted: 15-10-2021

Anna AT

Kerala University of Fisheries and Ocean Studies (KUFOS), Panangad, P.O. Kochi, Kerala, India

\section{Dinesh K}

Kerala University of Fisheries and Ocean Studies (KUFOS),

Panangad, P.O. Kochi, Kerala, India
Corresponding Author:

Anna AT

Kerala University of Fisheries and Ocean Studies (KUFOS), Panangad, P.O. Kochi, Kerala, India

\section{Feasibility study and seasonal variations in physico- chemical parameters of water and soil quality analysis and management of the Vannamei shrimp farms in Kerala, India}

\author{
Anna AT and Dinesh K
}

DOI: https://doi.org/10.22271/fish.2021.v9.i6b.2592

\begin{abstract}
This study aims at assessing the Physico-chemical properties of water and bottom soil quality in semiintensive vannamei shrimp farms in Kerala, India. Six different farms were selected from four districts of Kerala based on the stocking density and the technical experience in vannamei shrimp farming, as designated as Farm1, 2, 3, 4, 5 and Farm 6 including triplicates of ponds with a stocking density of 15, $25,30,40,50$ and $60 / \mathrm{m}^{2}$. The majority of the water quality parameters do not show any significant $(p<0.05)$ differences between farms except dissolved oxygen and temperature recorded in the morning, ammonia and silicate showed a significant difference in winter crop and nitrite showed a considerable difference in the summer crop. Most of the soil quality parameters do not show any significant difference in both seasonal crops except the organic carbon value recorded in the summer season showed highly significant differences. All the parameters were maintained within the optimum level for the vannamei shrimp farming due to the continuous and effective use of good quality water and soil probiotics and minerals and responsible culture management.
\end{abstract}

Keywords: Penaeus vannamei, physico-chemical properties, water quality, soil quality, semi-intensive farm, farm management

\section{Introduction}

Shrimp farming plays a pivotal role in the socio-economic condition of the coastal population of India by way of contributing to foreign exchange earnings and livelihood options. Recently, there is a marked shift from the farming of indigenous black tiger shrimp, Penaeus monodon to the culture of exotic white-legged shrimp, Penaeus vannamei in the shrimp farming sector in India, following the successful introduction of the latter. With the evolution of shrimp aquaculture over the years from traditional, extensive and semi-intensive culture methods to modern intensive culture practices following the introduction of exotic Penaeus vannamei in 2009. Vannamei farming has got an enormous response from the farmers due to the availability of high-quality SPF seed, amenability of the species to high stocking density and high production rates achieved.

Regular monitoring of water quality is very essential. The overall productivity of a water body, as well as the biology of cultured organisms, is influenced by the physico-chemical and biological features of water. For many years, water quality management has been considered one of the most significant components of pond aquaculture, but the management of ponds has received less attention. There is increasing evidence that the condition of pond bottoms and the exchange of substances between soil and water strongly influence water quality ${ }^{[1]}$. More attention is being devoted to the study of pond soils, and practical aquaculturists are beginning to seek information on pond bottom management.

Shrimp physiology directly depends on the water temperature in culture ponds and therefore, the key to successful shrimp farming lies in adapting the culture technique and farming protocols as per the season. Winter is the most challenging season for shrimp farming than summer or monsoon as the water temperatures remain low for an extended period of time. Therefore, this study aims to determine the water and soil quality condition for the 
sustainability of vannamei shrimp culture in the four Districts of Kerala, India as per the season and find its management strategies for further improvement.

\section{Materials and Methods \\ Study area}

For the purpose of the study, the State of Kerala was geographically divided into three zones viz., North, Central and South. The study was confined to four districts selected purposively to represent each of the zones. The present investigation carried out in brackish water shrimp farms at Ernakulum, Thrissur, Kollam, and Kannur Districts were shown in Fig: 1. Two crop cycles of varying stocking densities (SD) and areas with shorter crop durations had been undertaken during the period from October 2018 to August 2019 (winter and summer crops) and all the crops were taken in ponds of varied sizes ranging from $0.40-1.011$ ha with the water depth of 1.2- $1.5 \mathrm{~m}$.

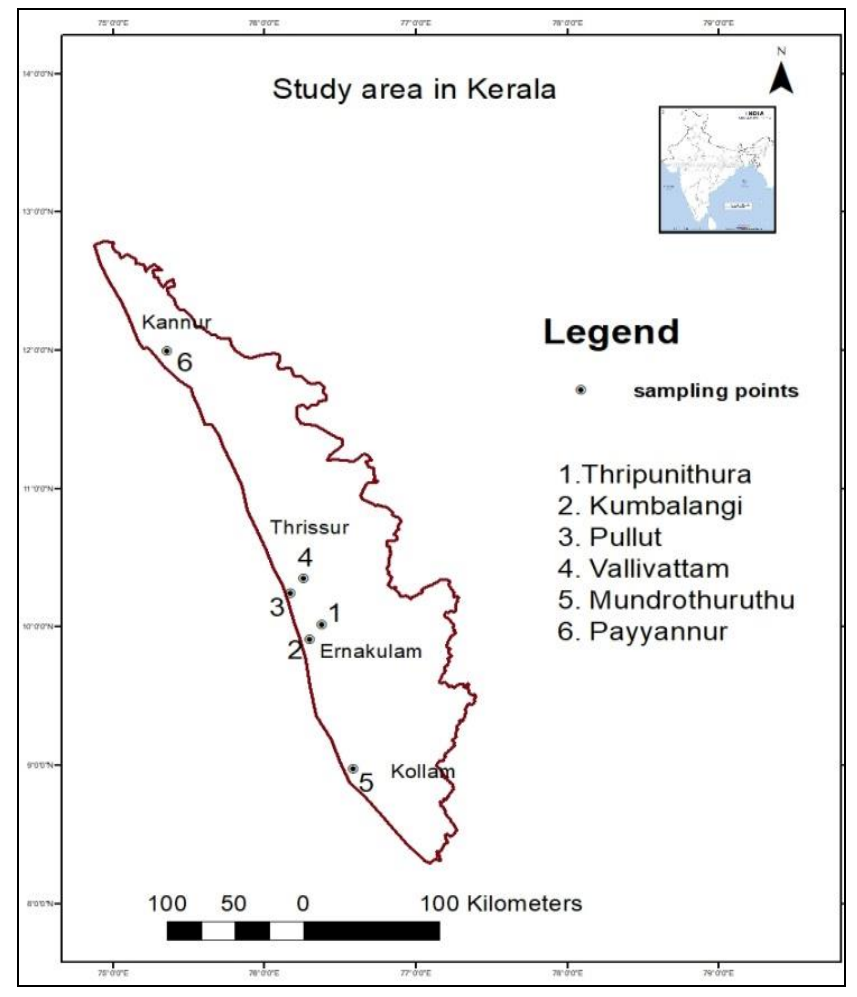

Fig 1: Location map of research area
Analysis of physico-chemical parameters of water sample The physico-chemical parameters such as temperature $\left({ }^{\circ} \mathrm{C}\right)$, $\mathrm{pH}$, dissolved oxygen $(\mathrm{mg} / \mathrm{l})$ were measured at $07.00 \mathrm{am}$ in the morning and $6.00 \mathrm{pm}$ in the evening using a mercury thermometer, digital $\mathrm{pH}$ meter and digital DO meter respectively and salinity (ppt) was measured by refractometer in the morning at $7.00 \mathrm{am}$, at fifteen days interval. Total alkalinity and total hardness were analysed at 15 days intervals following standard method of APHA [2] 1998). Turbidity $(\mathrm{cm})$ was measured using Secchidisc at 15 days interval. The level of total ammonia (NH3)-N, nitrite-N (No2$\mathrm{N})$, nitrate-N (No3-N), Phosphate (PO4-P) and silicate concentration were measured as per the standard method of $\mathrm{APHA}^{[2]}$ at fifteen days intervals and it was expressed as $\mathrm{mg}$ L-1.

\section{Analysis of soil characteristics}

Soil $\mathrm{pH}$ was measured by a sediment $\mathrm{pH}$ meter (ESICO, India). The electrical conductivity was measured by the 'ELICO CM 183-EC-TDS' Analyzer. The soil organic carbon was analysed by the chromic acid oxidization method (Walkley \& Black, 1934) ${ }^{[3]}$. The redox potential of oxidationreduction potential (ORP) by ORP meter was measured at the laboratory. The available phosphorus procedure was used to digest samples with sulphuric acid and hydrogen peroxide. Digested samples were processed for analysis on a spectrophotometer using standard method of APHA ${ }^{[4]}$.

\section{Statistical analysis}

Data were presented as the mean \pm standard error (SE) of triplicates. Statistical analysis was performed using SPSS statistical software (version 20.0). The significant difference between means was determined using Duncan's multiple range test (DMRT). The level of significance was set up at $p$ $\leq 0.05$.

\section{Results and Discussion \\ Physical-chemical quality parameters of water}

The success of aquaculture can be secure by selecting a farm site with suitable soil and high-quality water availability, it is very critical to understand the pond soil and water characteristics and their optimum requirements to increase the productivity of the ponds. The mean $\pm \mathrm{SE}$ values of the water quality parameters during the experimental period are given in Table $1 \& 2$.

Table 1: Overall water quality measurements during 120 days of the culture trial winter season (October 2018- February 2019). Data are presented as mean \pm standard error (Mean $\pm \mathrm{SE}$ ). Values in the same row having the same superscripts are not significantly different $(P>0.05$ )

\begin{tabular}{|c|c|c|c|c|c|c|}
\hline Parameters & Farm 1 & Farm 2 & Farm 3 & Farm 4 & Farm 5 & Farm 6 \\
\hline Salinity (ppt) & $10.15^{\mathrm{c}} \pm .21$ & $9.33^{\mathrm{b}} \pm .22$ & $13.00^{\mathrm{d}} \pm .17$ & $13.15^{\mathrm{d}} \pm .07$ & $17.37^{\mathrm{e}} \pm .23$ & $5.59^{\mathrm{a}} \pm .26$ \\
\hline $\mathrm{pH} \mathrm{AM}$ & $7.65^{\mathrm{bc}} \pm .02$ & $7.62^{\mathrm{b}} \pm .02$ & $7.75^{\mathrm{d}} \pm .02$ & $7.47^{\mathrm{a}} \pm .03$ & $7.69^{c} \pm .02$ & $8.06^{\mathrm{e}} \pm .03$ \\
\hline pH PM & $8.13^{\mathrm{b}} \pm .00$ & $8.11^{\mathrm{b}} \pm .02$ & $8.26^{\mathrm{c}} \pm .02$ & $7.98^{\mathrm{a}} \pm .02$ & $8.24^{\mathrm{c}} \pm .03$ & $8.62^{\mathrm{d}} \pm .04$ \\
\hline DO AM $(\mathrm{mg} / \mathrm{l})$ & $4.72^{\mathrm{a}} \pm .02$ & $4.98^{\mathrm{b}} \pm .05$ & $5.83^{\mathrm{d}} \pm .06$ & $5.16^{\mathrm{c}} \pm .01$ & $5.82^{\mathrm{d}} \pm .07$ & $6.20^{\mathrm{e}} \pm .02$ \\
\hline DO PM (mg/l) & $5.11^{\mathrm{a}} \pm .04$ & $6.03^{\mathrm{b}} \pm .01$ & $6.75^{\mathrm{c}} \pm .05$ & $6.11^{\mathrm{b}} \pm .03$ & $6.65^{c} \pm .04$ & $7.24^{\mathrm{d}} \pm .07$ \\
\hline Temperature AM $\left({ }^{\circ} \mathrm{C}\right)$ & $28.82^{\mathrm{d}} \pm .02$ & $29.08^{\mathrm{e}} \pm .01$ & $29.22^{f} \pm .03$ & $28.46^{\mathrm{c}} \pm .04$ & $27.80^{\mathrm{b}} \pm .03$ & $27.66^{\mathrm{a}} \pm .07$ \\
\hline Temperature PM $\left({ }^{\circ} \mathrm{C}\right)$ & $31.34^{\mathrm{f}} \pm .05$ & $30.89^{\mathrm{d}} \pm .06$ & $31.07^{\mathrm{e}} \pm .02$ & $30.71^{\mathrm{c}} \pm .02$ & $29.84^{\mathrm{a}} \pm .03$ & $30.30^{\mathrm{b}} \pm .06$ \\
\hline Transparency $(\mathrm{cm})$ & $34.00^{\mathrm{c}} \pm .32$ & $33.63^{\mathrm{c}} \pm .74$ & $30.04^{\mathrm{b}} \pm .07$ & $29.93^{\mathrm{b}} \pm .49$ & $25.19^{\mathrm{a}} \pm .39$ & $31.41^{\mathrm{b}} \pm .85$ \\
\hline Total Alkalinity $(\mathrm{mg} / \mathrm{l})$ & $136.63^{\mathrm{a}} \pm 4.62$ & $157.44^{\mathrm{b}} \pm 3.77$ & $152.33^{\mathrm{b}} \pm 1.02$ & $149.70^{\mathrm{b}} \pm 2.86$ & $153.93^{\mathrm{b}} \pm 6.50$ & $171.81^{\mathrm{c}} \pm 4.00$ \\
\hline Total Hardness (mg/l) & $1420.74^{\mathrm{a}} \pm 13.32$ & $1558.33^{\mathrm{a}} \pm 29.00$ & $2017.59^{\mathrm{d}} \pm 16.93$ & $2359.89^{\mathrm{e}} \pm 24.66$ & $2793.89^{f} \pm 27.72$ & $1944.63^{\mathrm{c}} \pm 11.73$ \\
\hline Ammonia (mg/l) & $.103^{\mathrm{a}} \pm .009$ & $.204^{\mathrm{c}} \pm .004$ & $.219^{\mathrm{d}} \pm .002$ & $.175^{\mathrm{b}} \pm .005$ & $.233^{\mathrm{e}} \pm .001$ & $.309^{\mathrm{f}} \pm .000$ \\
\hline Nitrite $(\mathrm{mg} / \mathrm{l})$ & $.062^{\mathrm{a}} \pm .003$ & $.107^{\mathrm{c}} \pm .005$ & $.100^{\mathrm{c}} \pm .002$ & $.084^{\mathrm{b}} \pm .004$ & $.105^{\mathrm{c}} \pm .002$ & $.140^{\mathrm{d}} \pm .005$ \\
\hline Nitrate $(\mathrm{mg} / \mathrm{l})$ & $.112^{\mathrm{a}} \pm .004$ & $.124^{\mathrm{b}} \pm .001$ & $.130^{\mathrm{b}} \pm .003$ & $.111^{\mathrm{a}} \pm .005$ & $.120^{\mathrm{ab}} \pm .001$ & $.166^{\mathrm{c}} \pm .004$ \\
\hline Phosphate (mg/l) & $.278^{\mathrm{b}} \pm .001$ & $.335^{\mathrm{c}} \pm .005$ & $.329^{\mathrm{c}} \pm .002$ & $.255^{\mathrm{a}} \pm .001$ & $.362^{\mathrm{d}} \pm .004$ & $.326^{\mathrm{c}} \pm .004$ \\
\hline Silicate $(\mathrm{mg} / \mathrm{l})$ & $.075^{\mathrm{c}} \pm .003$ & $.063^{\mathrm{b}} \pm .002$ & $.105^{\mathrm{e}} \pm .001$ & $.050^{\mathrm{a}} \pm .000$ & $.084^{\mathrm{d}} \pm .001$ & $.063^{\mathrm{b}} \pm .001$ \\
\hline
\end{tabular}


Table 2: Overall water quality measurements during 120 days of the culture trial in summer season (April 2019- August 2019). Data are presented as mean \pm standard error (Mean $\pm \mathrm{SE}$ ). Values in the same row having the same superscripts are not significantly different $(P>0.05)$

\begin{tabular}{|c|c|c|c|c|c|c|}
\hline Parameters & Farm 1 & Farm 2 & Farm 3 & Farm 4 & Farm 5 & Farm 6 \\
\hline Salinity (ppt) & $17.78^{\mathrm{a} \pm .34}$ & $19.52^{\mathrm{b}} \pm .19$ & $23.15^{\mathrm{d}} \pm .30$ & $24.04^{\mathrm{e}} \pm .27$ & $21.33^{\mathrm{c}} \pm .06$ & $23.37^{\mathrm{de}} \pm .27$ \\
\hline $\mathrm{pH} \mathrm{AM}$ & $7.53^{\mathrm{ab}} \pm .01$ & $7.78^{\mathrm{c}} \pm .04$ & $7.49^{\mathrm{a}} \pm .02$ & $7.60^{\mathrm{b}} \pm .02$ & $7.72^{\mathrm{c}} \pm .02$ & $8.07^{\mathrm{d}} \pm .03$ \\
\hline $\mathrm{pH} \mathrm{PM}$ & $8.07^{\mathrm{b}} \pm .00$ & $8.23^{\mathrm{c}} \pm .03$ & $7.92^{\mathrm{a}} \pm .01$ & $8.09^{\mathrm{b}} \pm .01$ & $8.20^{\mathrm{c}} \pm .01$ & $8.56^{\mathrm{d}} \pm .03$ \\
\hline DO AM (mg/l) & $4.82^{\mathrm{a}} \pm .00$ & $5.09^{\mathrm{b}} \pm .04$ & $5.07^{\mathrm{b}} \pm .01$ & $5.03^{\mathrm{b}} \pm .02$ & $5.24^{\mathrm{c}} \pm .02$ & $5.34^{\mathrm{d}} \pm .01$ \\
\hline DO PM (mg/l) & $5.66^{\mathrm{a}} \pm .03$ & $6.51^{\mathrm{c}} \pm .03$ & $6.68^{\mathrm{d}} \pm .03$ & $6.34^{\mathrm{b}} \pm .01$ & $7.01 \mathrm{e} \pm .05$ & $7.63^{f} \pm .04$ \\
\hline Temperature AM $\left({ }^{\circ} \mathrm{C}\right)$ & $31.95^{\mathrm{e}} \pm .04$ & $31.83^{\mathrm{d}} \pm .02$ & $31.62^{\mathrm{c}} \pm .03$ & $31.51^{\mathrm{c}} \pm .01$ & $30.17^{\mathrm{b}} \pm .01$ & $29.85^{\mathrm{a}} \pm .05$ \\
\hline Temperature PM $\left({ }^{\circ} \mathrm{C}\right)$ & $32.80^{\mathrm{c}} \pm .04$ & $33.20^{\mathrm{d}} \pm .08$ & $32.20^{\mathrm{b}} \pm .04$ & $32.73^{\mathrm{c}} \pm .10$ & $33.29^{\mathrm{d}} \pm .02$ & $31.97^{\mathrm{a}} \pm .03$ \\
\hline Transparency $(\mathrm{cm})$ & $34.89^{\mathrm{cd}} \pm .32$ & $31.63^{\mathrm{b}} \pm .58$ & $32.78^{\mathrm{bc}} \pm 1.12$ & $32.30^{\mathrm{b}} \pm .78$ & $24.81^{\mathrm{a}} \pm .99$ & $35.93^{\mathrm{d}} \pm .32$ \\
\hline Total Alkalinity $(\mathrm{mg} / \mathrm{l})$ & $135.78^{\mathrm{a}} \pm 6.04$ & $173.93^{\mathrm{c}} \pm 4.49$ & $147.81^{\mathrm{ab}} \pm 7.60$ & $134.89^{\mathrm{a}} \pm 6.08$ & $160.48^{\mathrm{bc}} \pm 6.32$ & $200.11^{\mathrm{d}} \pm 4.88$ \\
\hline Total Hardness (mg/l) & $3504.48^{\mathrm{b}} \pm 12.06$ & $4022.22^{c} \pm 9.58$ & $3010.11^{\mathrm{a}} \pm 9.17$ & $5404.26^{\mathrm{e}} \pm 18.28$ & $4977.15^{\mathrm{d}} \pm 12.62$ & $5401.44^{\mathrm{e}} \pm 14.56$ \\
\hline Ammonia $(\mathrm{mg} / \mathrm{l})$ & $.167^{\mathrm{a}} \pm .004$ & $.278^{\mathrm{d}} \pm .007$ & $.294^{\mathrm{d}} \pm .004$ & $.234^{b} \pm .006$ & $.253^{\mathrm{c}} \pm .006$ & $.332^{\mathrm{e}} \pm .007$ \\
\hline Nitrite $(\mathrm{mg} / \mathrm{l})$ & $.076^{\mathrm{a}} \pm .007$ & $.124^{\mathrm{c}} \pm .008$ & $.110^{\mathrm{b}} \pm .004$ & $.107^{\mathrm{b}} \pm .002$ & $.139^{\mathrm{d}} \pm .003$ & $.144^{\mathrm{d}} \pm .001$ \\
\hline Nitrate $(\mathrm{mg} / \mathrm{l})$ & $.093^{\mathrm{a}} \pm .002$ & $.137^{\mathrm{bc}} \pm .006$ & $.146^{\mathrm{cd}} \pm .002$ & $.126^{\mathrm{b}} \pm .003$ & $.153^{\mathrm{d}} \pm .003$ & $.168^{\mathrm{e}} \pm .006$ \\
\hline Phosphate $(\mathrm{mg} / \mathrm{l})$ & $.235^{\mathrm{a} \pm .003}$ & $.291^{\mathrm{b}} \pm .004$ & $.319^{c} \pm .002$ & $.322^{\mathrm{c}} \pm .005$ & $.398^{\mathrm{e}} \pm .001$ & $.343^{\mathrm{d} \pm .004}$ \\
\hline Silicate $(\mathrm{mg} / \mathrm{l})$ & $.064^{\mathrm{a}} \pm .002$ & $.084^{\mathrm{b}} \pm .001$ & $.135^{\mathrm{c}} \pm .006$ & $.075^{\mathrm{ab}} \pm .006$ & $.062^{\mathrm{a}} \pm .005$ & $.071^{\mathrm{ab}} \pm .002$ \\
\hline
\end{tabular}

\section{Temperature}

The temperature didn't fluctuate considerably in different seasons from $27.66 \pm .07{ }^{\circ} \mathrm{C}$ to $31.95 \pm .04{ }^{\circ} \mathrm{C}$ in the morning and $29.85 \pm .05{ }^{\circ} \mathrm{C}$ to $32.80 \pm .04{ }^{\circ} \mathrm{C}$ in the evening in both crops. There was no significant difference observed in different farms in the evening in both seasons except the temperature value observed in the morning of first seasonal crops showed significant difference $(p<0.05)$. The temperatures observed in the study area were still suitable for vannamei shrimp culture. VanWyk \& Scrapa (1999) [5] reported that, temperature ranging from 24 to $32{ }^{\circ} \mathrm{C}$ is optimum for penaeid larval culture. Although the white shrimp L. vannamei can survive over a wide temperature range $\left(15-35^{\circ} \mathrm{C}\right)$, the optimal range for the growth of this species is considered to be $28-32{ }^{\circ} \mathrm{C}$. In the winter season, farmers avoid aeration during the early morning hours particularly from 2 am to $6 \mathrm{am}$. This would help them to maintain warmer water temperature during this period, but those keeping oxygen tablets on the maintenance of dissolved oxygen levels in the ponds and also by the application of Calcium oxide clumps during the night and subsequent heat released during the application which also helps to maintain the bottom water temperature of the ponds.

\section{pH}

The lowest and highest level of $\mathrm{pH}$ recorded in the morning was $7.47 \pm .03$ to $8.06 \pm .03$ in the winter crop and $7.49 \pm .02$ to $8.07 \pm .03$ in the summer crop; the lowest and highest $\mathrm{pH}$ levels recorded in the evening was $7.98 \pm .02$ to $8.62 \pm .04$ and $7.92 \pm .01$ to $8.56 \pm .03$ in the winter and summer crop respectively ${ }^{[6]}$. Soundarapandian and Gunalan, (2008) recommended a favourable $\mathrm{pH}$ range of 6 -8.6 for $L$. vannamei. The $\mathrm{pH}$ of the pond water was always within the optimum range $(6.6$ - 8.5) recommended for shrimp farming $\left[{ }^{7]}\right.$. In the present experimental study, $\mathrm{pH}$ value recorded with in the optimum level and it would not be varied more than 0.5 in a day through regular monitoring and application of lime and dolomite.

\section{Salinity}

The water salinity in the culture ponds during the experimental period ranged from $5.59 \pm .26$ to $17.37 \pm .23 \mathrm{ppt}$ and $17.78 \pm .34$ to $24.04 \pm .27$ ppt in winter and summer crop respectively. It doesn't show any significant difference in both seasonal crops between farms. The low salinity had observed in the winter season, primarily due to the dilution of pond water by rains due to severe floods before starting the crop period. It is preferable to have salinities of above $20 \mathrm{ppt}$ for the winter crop. Saline water is known to be able to retain heat for a longer time than freshwater and helps to maintain better water temperatures. The salinity value reported in all vannamei shrimp farms in Kerala becomes below 20 ppt for the winter crop. Even though, the vannamei shrimp farmers in Kerala have been done winter crops very successfully. The optimum range of salinity most suitable for shrimp culture is about 15-25 ppt ${ }^{[1,8]}$ while Chien, (1992) ${ }^{[9]}$ recommended a salinity level of 10-25 ppt for shrimp culture.

\section{Dissolved oxygen}

The DO concentration is the major critical water quality variable in aquaculture ${ }^{[10]}$. Dissolved oxygen in the present culture trial, was recorded from $4.72 \pm .02$ to $6.20 \pm .02 \mathrm{mg} / \mathrm{l}$ and $4.82 \pm .00$ to $5.34 \pm .01 \mathrm{mg} / \mathrm{l}$ in the morning and $5.11 \pm .04$ to $7.24 \pm .07 \mathrm{mg} / \mathrm{l}$ and $5.66 \pm .03$ to $7.63 \pm .04 \mathrm{mg} / \mathrm{l}$ in the evening in crop 1 and crop 2 respectively. No significant difference existed in DO levels $(p>0.05)$ between different farms. The vannamei farmers in Kerala used oxygen enhancer products in the case of emergency, even though the aeration is providing. They maintained a dissolved oxygen level at above $5 \mathrm{ppm}$ is a blessing to the growing of shrimp. For this, they used a combination of paddle wheel aerators and air diffusers for better efficiency. The patented product like Naulgi also helps to maintain high dissolved oxygen levels in culture ponds.

\section{Total alkalinity and Total hardness}

The Total alkalinity levels were above the requirement given by Boyd et al., (2002) ${ }^{[11]}$ and it was ranged from the mean value of 139.67 to $171.81 \mathrm{mg} / \mathrm{l}$ and 134.89 to $200.11 \mathrm{mg} / \mathrm{l}$ in winter and summer crop respectively. During the study period, the mean values of Total hardness were recorded and they ranged from $1420.74 \pm 13.32$ to $2793.89 \pm 27.72 \mathrm{mg} / \mathrm{l}$ and $3010.11 \pm 9.17$ to $5401.44 \mathrm{mg} / \mathrm{l}$ in crop 1 and crop 2 respectively. The highest level of Total hardness was reported in the summer season in all farms might due to high salinity content. The statistical analysis showed that the values were not significantly different $(P>0.05)$ between farms.

\section{Transparency $(\mathbf{c m})$}

According to Wahab et al. (1994) ${ }^{[12]}$, the transparency of productive water bodies should be $40 \mathrm{~cm}$ or less. In the present culture trial, water transparency was ranged from $25.19 \pm .39$ to $34.00 \pm .32 \mathrm{~cm}$ and $24.81 \pm .99$ to $35.93 \pm .32 \mathrm{~cm}$ in 
winter and summer crop respectively. The statistical analysis showed that, it doesn't show any significant difference between farms in both seasonal crops. In farm 4, the farmer maintained a transparency level at $25 \mathrm{~cm}$ for the better growth of zooplankton. This is achieved through chain dragging at the pond bottom at regular intervals on all sides of the pond.

\section{Ammonia, Nitrite and Nitrate}

Ammonia (NH3-N) content observed in culture trial was $.103 \pm$, 009 to $.309 \pm .000 \mathrm{mg} / \mathrm{l}$ and $.167 \pm .004$ to $.332 \pm .007$ $\mathrm{mg} / \mathrm{l}$ in winter and summer crop respectively. Ammonia-N was within the tolerance limit reported by Lin \& Chen (2001) ${ }^{[13]}$. Nitrite (NO2) content observed in the present study was $.062 \pm .003$ to $.140 \pm .005 \mathrm{mg} / \mathrm{l}$ and $.076 \pm .001$ to $.144 \pm .001 \mathrm{mg} / \mathrm{l}$ in crop 1 and crop 2 respectively. Nitrite-N level in water was well below the toxic limits reported for this species by Lin \& Chen (2003) ${ }^{[14]}$. A safe nitrate level of $<1.0 \mathrm{mg} / \mathrm{l}$ has been suggested for penaeid shrimp (Karthikeyan \& Srimurali, 1995) ${ }^{[15]}$. Although in the present study, the nitrate levels in the range of $.111 \pm .005$ to $.166 \pm .004 \mathrm{mg} / \mathrm{l}$ and $.093 \pm .002$ to $.168 \pm .006 \mathrm{mg} / \mathrm{l}$ in winter and summer crop respectively. The one-way ANOVA result showed that ammonia level in winter crop and nitrite level in summer crop showed a significant difference. Optimum stocking density, proper feed management and sufficient aeration could help the vannamei shrimp farmers to maintain safe ammonia, nitrite and nitrate levels in the pond and also by the periodical application of good quality and optimum dosage water probiotics also help the farmers to maintain a stable nitrification process.

\section{Phosphate}

Phosphate (PO4-P) value obtained in the present culture trial was $.255 \pm .001$ to $.362 \pm .004 \mathrm{mg} / 1$ and $.235 \pm .003$ to $.398 \pm .001$ $\mathrm{mg} / \mathrm{l}$ in winter and summer crop respectively. It doesn't show any significant different in both the crops. According to Moyle (1946) ${ }^{[16]}$, inorganic phosphate concentration ranging from 0.05 to $0.1 \mathrm{ppm}$ and between 0.1 to $2 \mathrm{ppm}$ is considered as good and very good in culture ecosystems, respectively. He observed increased reactive phosphorus value due to the high input of feeds and fertilization in their culture system.

\section{Silicate}

The silicate value observed in the present culture trial ponds was ranged from $.050 \pm .000$ to $.105 \pm .001 \mathrm{mg} / \mathrm{l}$ and $.064 \pm .002$ to $.135 \pm .006$ in winter and summer crop respectively. It was comparatively higher in Farm 3 in both seasonal crops might due to the use of diatom enhancer during the culture period. It showed a significant difference in winter crop $(p<0.05)$. Altogether the water quality parameters were not varied substantially during the entire study period, nullifying their influence on the performance of the species.

\section{Soil quality parameters}

The pond environment is a crucial in the outcome of aquaculture operations. The seasonal variations in different soil quality parameters recorded during the study periods were shown in Fig: 2-6.

\section{pH}

The soil $\mathrm{pH}$ during the culture period ranged from $6.88 \pm .06$ to $7.21 \pm .04$ in winter and 7.04 \pm .02 to $7.40 \pm .03$ in summer crop respectively. Soundarapandian and Gunalan, (2008) [6] recommended that, the favourable soil $\mathrm{pH}$ in the range of 7.68.6 for L. vannamei. The optimum range of soil $\mathrm{pH}$ in the present study area reflects that the effect of monitoring and frequent applications of liming materials.

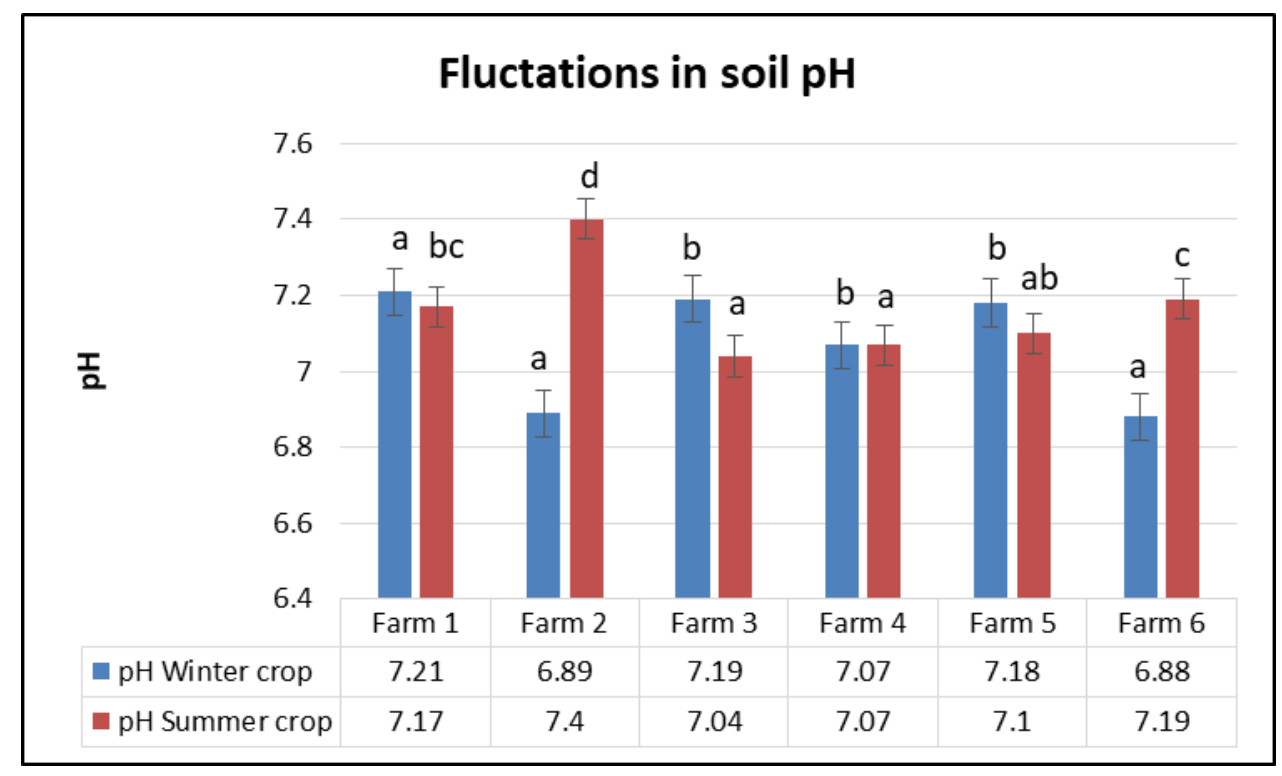

Fig 2: Seasonal fluctuations in soil pH in different crop seasons (October 2018- August 2019)

\section{Electrical conductivity}

Conductivity is an index of the total ionic content of water and therefore indicates the freshness of the water ${ }^{[17]}$. The mean value of electrical conductivity ranged from $1.23 \pm .04$ to $2.36 \pm .08 \mathrm{dS} / \mathrm{m}$ and $3.27 \pm .04$ to $4.95 \pm .05 \mathrm{dS} / \mathrm{m}$ in winter and summer crops respectively. In the present study, electrical conductivity becomes below the optimal limit in all farms in winter crop might due to continuous rains due to severe floods before starting and also between the crop period but in summer crop season, majority of the farms maintained an optimum level. 


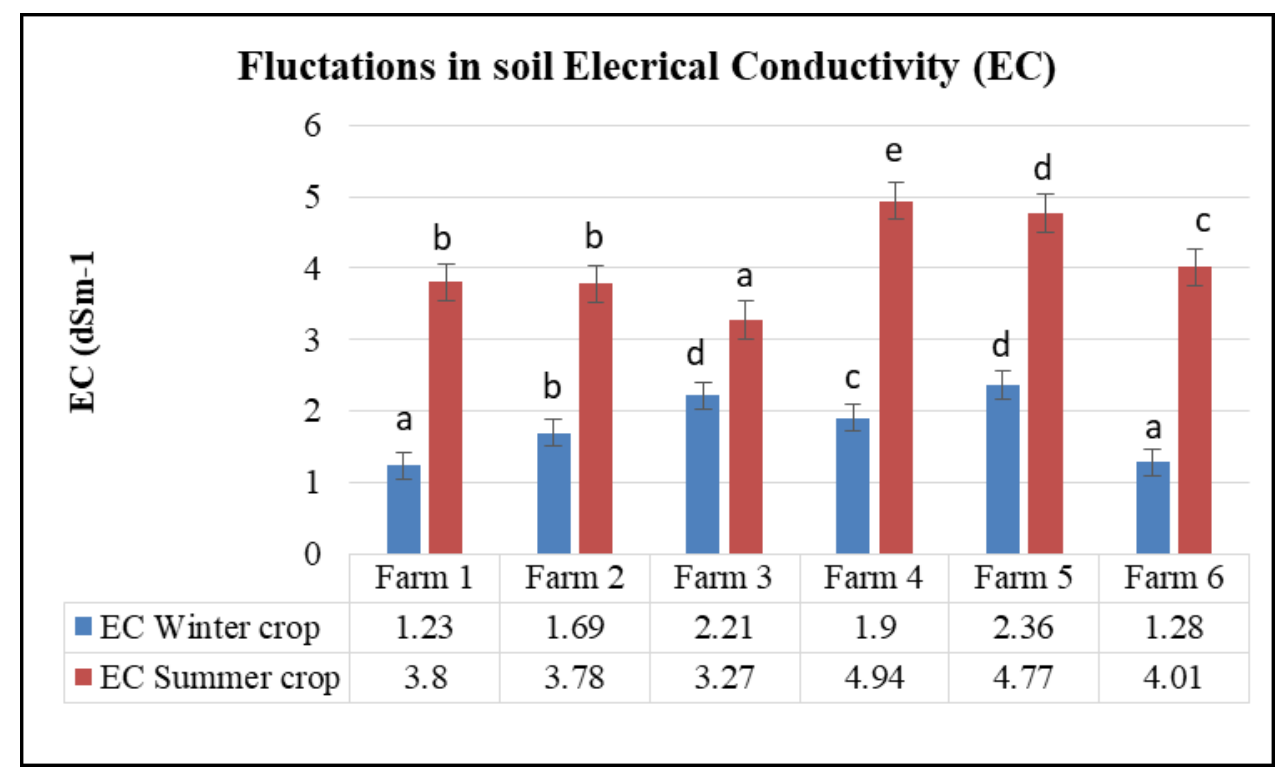

Fig 3: Seasonal fluctuations in soil Electrical Conductivity in different crop seasons (October 2018- August 2019)

\section{Redox potential}

The oxidation-reduction potential value in the present study area was on the negative side ranging from ${ }^{-} 178.74 \pm 1.83$ to $-94.30 \pm 2.61 \mathrm{mV}$ and ${ }^{-} 135.41 \pm 2.49$ to ${ }^{-} 89.56 \pm .33 \mathrm{mV}$, thus indicating the fact that the sediment environment is increasingly anaerobic. A similar observation on the levels of oxidation-reduction potential $(-160$ to $-190 \mathrm{mV}$ ) in extensive shrimp culture systems of Kerala has been reported by (Krishnani et al., 2011) ${ }^{[18]}$. Even though these higher anaerobic conditions of the ponds were controlled through higher aeration and mixing.

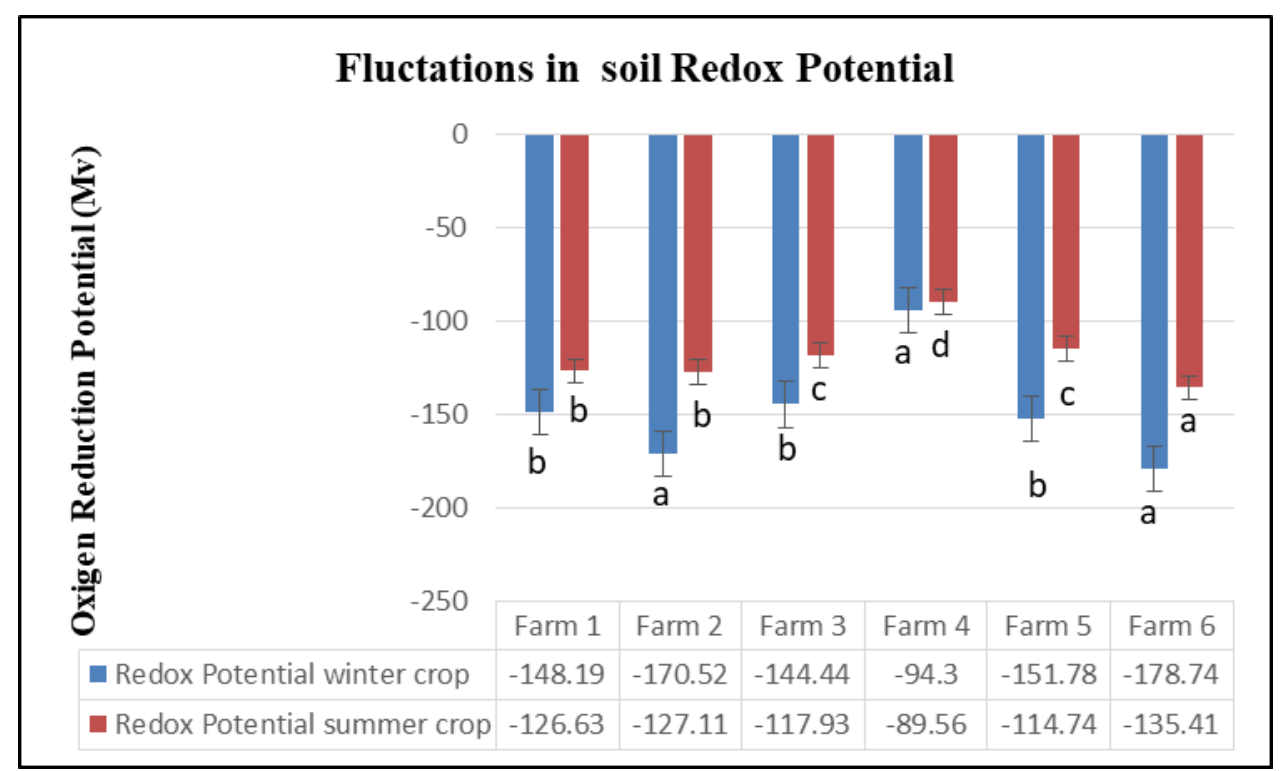

Fig 4: Seasonal fluctuations in soil Redox Potential values in different crop seasons (October 2018- August 2019)

\section{Organic carbon}

The mean value of organic carbon observed in the present study was in the range of $.632 \pm .026$ to $1.133 \pm .013 \%$ and $.950 \pm .002$ to $1.282 \pm .002 \%$ in winter and summer crop respectively. Boyd and Green, (2002) ${ }^{[19]}$ recommended that, the range of organic carbon $1.0-3.0 \%$ is the best range for coastal aquaculture. 


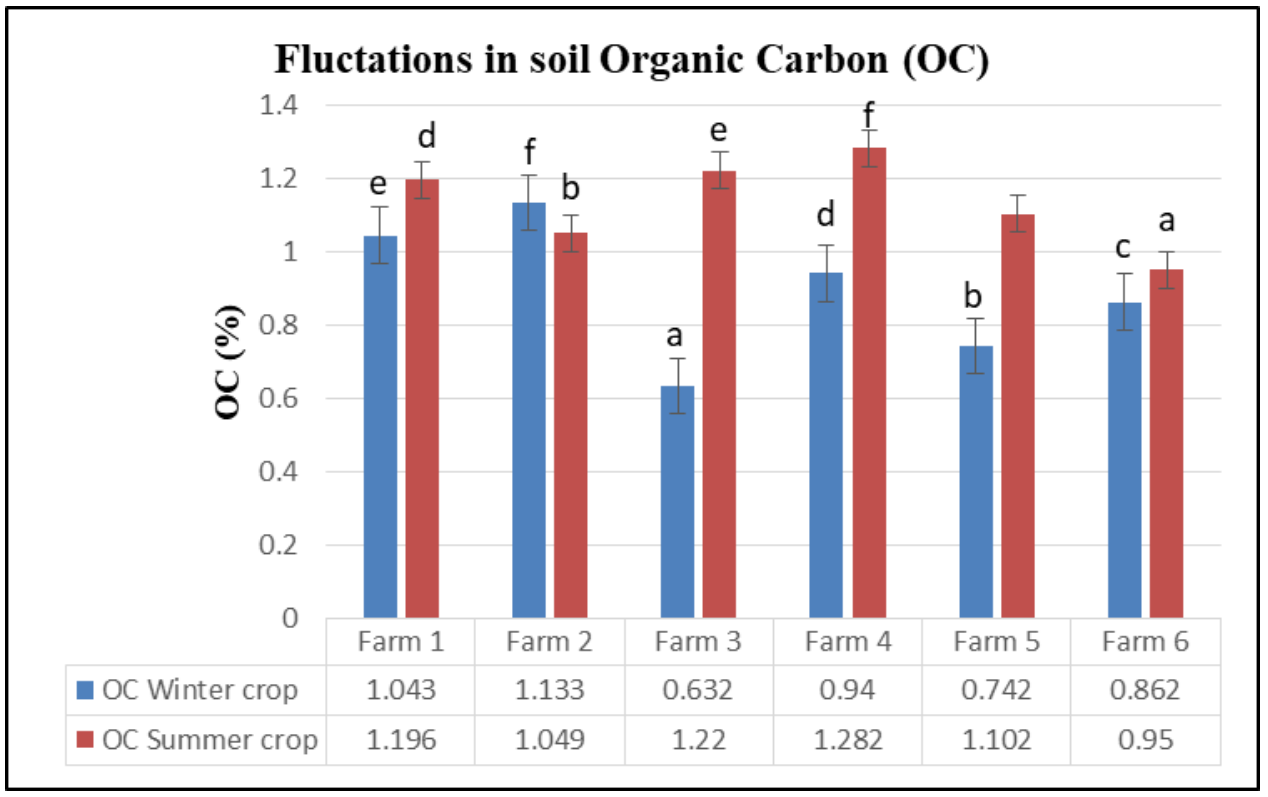

Fig 5: Seasonal fluctuations in soil Organic Carbon in different crop seasons (October 2018- August 2019)

\section{Available phosphorus}

Masuda and Boyd, (1994) ${ }^{[20]}$ found about two-thirds of phosphorus applied to ponds in feed accumulates in bottom soils. The available phosphorus value reported in the present study area were $22.54 \pm .09$ to $43.05 \pm .24 \mathrm{Kg} / \mathrm{ha}$ and $33.99 \pm .21$ to $56.43 \pm .41 \mathrm{Kg} / \mathrm{ha}$ in winter and summer crop respectively. This value is highest in summer crops compared to winter crops might be due to shrimp consuming more feed than under normal conditions and also it shows erratic feeding behaviour during this period but the majority of the vannamei shrimp farmers feed the shrimp as per the feeding chart and environmental conditions and also tried to feed more in the morning and evening hours. Except for the soil electrical conductivity reported in winter crops, all other parameters were within safe permissible levels for shrimp farming as suggested by Boyd (1995) and Smith (1996) ${ }^{[1,21]}$. The results of one-way ANOVA showed that the majority of the soil quality parameters didn't show any significant differences between the farms $(P>0.05)$. Whereas, the organic carbon value showed highly significant differences $(P<0.01)$ in the summer season.

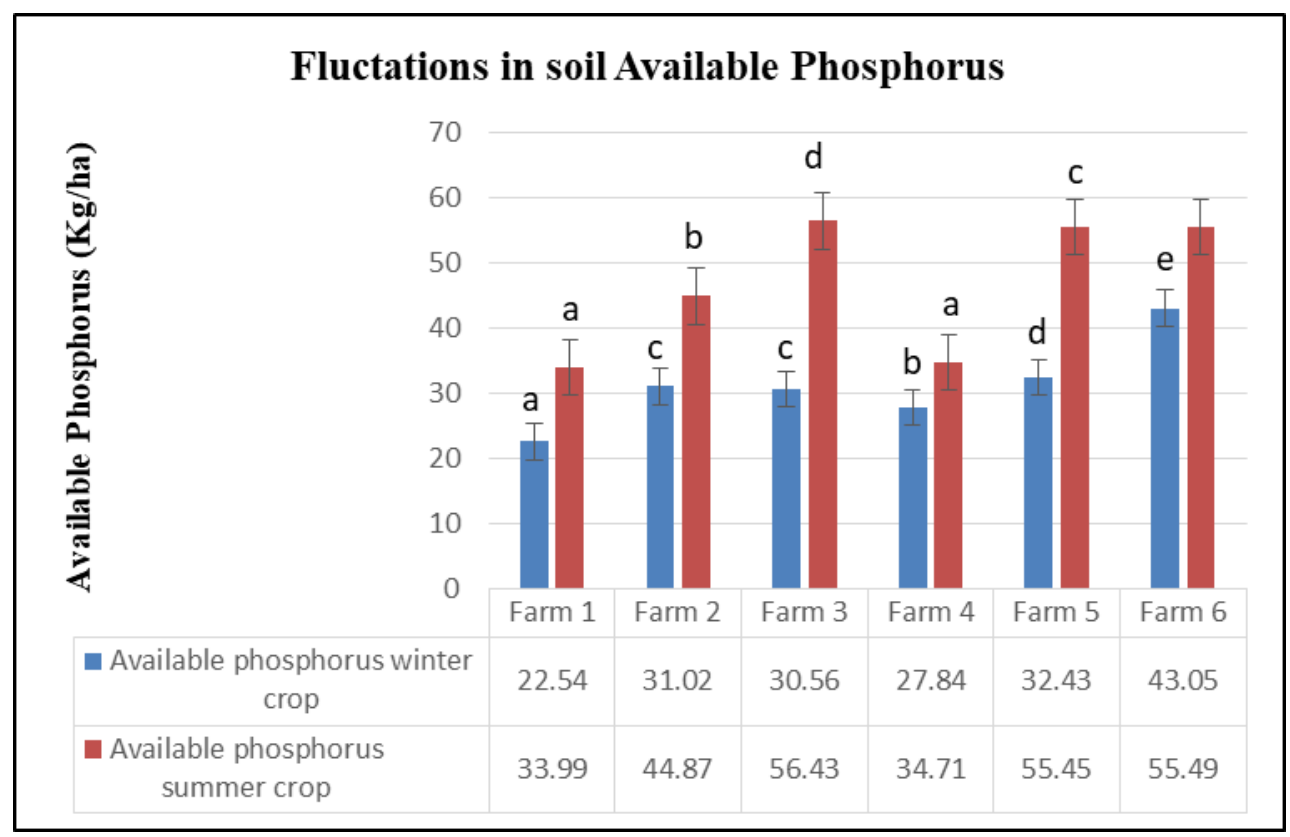

Fig 6: Seasonal fluctuations in soil Available Phosphorus in different crop seasons (October 2018- August 2019)

\section{Conclusion}

The study has provided information on the water and soil quality assessment and management status of vannamei shrimp farms in Kerala, India. The field and laboratory analysis on the water and soil quality revealed that the study area has a great potential for vannamei shrimp culture and development. Vannamei farmers in Kerala adopted strict biosecurity measures and Best Management Practices (BMP) to maintain optimum water and soil quality, proper feed management and good health shrimp through regular monitoring and also tried to use the latest and advanced feed and water additives for shrimp farming by adopting the best available technologies for farm production. 


\section{Acknowledgements}

The authors sincerely thank the vannamei shrimp farmers for responding to the interview and providing their valuable inputs. The authors are also thankful to Department of Aquaculture and Marine Biology for providing the facilities for the conduct of the work.

\section{References}

1. Boyd CE. Bottom Soils, Sediment and Pond Aquaculture, 1st ed., Chapman and Hall, New York 1995.

2. American Public Health Association (APHA). Standard methods for examination of water and waste water. 20th edn, Washington DC; USA 1988.

3. Walkley A, Black CA. An estimation of the Degtijareff method for determining soil organic matter and a proposed modification of the chromic acid titration method. Soil Science 1934;37:93-101.

4. American Public Health Association (APHA). Standard methods for the examination of water and waste water. 16th edn, Washington DC, USA 1989.

5. Van Wyk P, Scarpa J. Water quality and management. In: Farming Marine Shrimp in Recirculating Freshwater Systems (ed. by P. VanWyk, et al.), Florida Department of Agriculture and Consumer Services, Tallahassee, FL 1999, 128-138.

6. Soundarapandian P, Gunalan B. Recent technology for the survival and reproduction of gaint shrimp Penaeus monodon along south east coast of India. Int. J. Zoo. Res 2008;4(1):21-27. DOI:10.3923/ijzr.2008.21.27.

7. Tsai CK. Water quality management. In: D.M. Akiyama (Ed.), Proc. of South East Asia Shrimp Farm Management Workshop. American Soyabean Association, Singapore 1990, 56-63.

8. Baliao D. Environment Friendly Schemes in Intensive Shrimp Farming. SEAFDEC AQD 2000. ISBN 9718511-46-6.

9. Chien YH. Water quality requirements and managements for marine shrimp culture. In: Proceedings of the Special Session in Shrimp Farming. Wyban J (Ed.), World Aquacult. Soc., Baton Rouge, LA USA 1992,30-42.

10. Boyd CE. Water Quality Management and Aeration in Shrimp Farming Fisheries and Allied Aquacultures Department Series No: 2. Auburn University, Alabama, USA 1989.

11. Boyd CE, Wood CW, Thunjai T. Pond soil characteristics and dynamics of soil organic matter and nutrients. In: K. McElwee, K. Lewis, M. Nidiffer, and P. Buitrago (Editors), Nineteenth Annual Technical Report. Pond Dynamics/Aquaculture CRSP, Oregon State University, Corvallis, Oregon 2002,1-10.

12. Wahab MA, Bergheim A, Brasten B. Water quality and partial mass budget in extensive shrimp ponds in Bangladesh. Journal of Aquaculture 2003;218(1):413423. DOI: $10.1016 / \mathrm{S} 0044-8486$ (03)00009-7.

13. Lin Y, Chen J. Acute toxicity of ammonia on Litopenaeus vannamei (Boone) juveniles at different salinity levels. J. Exp. Mar. Biol. Ecol 2001;259(1):109119. DOI:1016/S0022-0981(01)00227-1.

14. Lin Y, Chen J. Acute toxicity of nitrite on Litopenaeus vannamei (Boone) juveniles at different salinity levels. Aquaculture 2003;224:193-201. DOI:1016/S0048486 (03)00220-5.

15. Karthikeyan J, Srimurali M. Environmental impact analysis statement and environmental management plan report of a proposed aqua farm at Nellore in Andhra Pradesh. Indian J. Environ. Health 1995;37:251-264.

16. Moyle JB. Some indices of lake productivity. Transactions of the American Fisheries Society 1946;76:322-334.

17. Ogbeibu AE, Victor R. Hydrological studies of water bodies in the okomu forest reserves (sanctuary) in Southern Nigeria, physico-chemical hydrology. Tropical Freshwater Biology 1995;4:83-100.

18. Krishnani KK, Gupta BP, Muralidhar M, Saraswathy R, Pillai SM, Ponnusamy $\mathrm{K}$ et al. Soil and water characteristics of traditional paddy and shrimp fields of Kerala. Indian Journal of Fisheries 2011;58(4):71-77.

19. Boyd CE, Green BW. Coastal Water Quality Monitoring in Shrimp Farming Areas, An Example from Honduras. Report prepared under the World Bank, NACA, WWF and FAO Consortium Program on Shrimp Farming and the Environment 2002,29p.

20. Masuda K, Boyd CE. Phosphorus Fractions in Soil and Water of Aquaculture Ponds Built on Clayey Ultisols at Auburn, Alabama. J. World Aquaculture Society 1994;25(3):379-395. https://doi.org/10.1111/j.17497345.1994.tb00222.x.

21. Smith PT. Physical and chemical characteristics of sediments from prawn farms and mangrove habitats on the Clarence River, Australia. Aquaculture 1996;146( ' 1 2):47-83. https://doi.org/10.1016/S0044-8486 (96)013610 . 